Trinity University

Digital Commons@ Trinity

English Faculty Research

English Department

6-2005

\title{
Copyrighting American History: International Copyright and the Periodization of the Nineteenth Century
}

Claudia Stokes

Trinity University, cstokes@trinity.edu

Follow this and additional works at: https://digitalcommons.trinity.edu/eng_faculty

Part of the English Language and Literature Commons

\section{Repository Citation}

Stokes, C. (2005). Copyrighting American history: International copyright and the periodization of the nineteenth century. American Literature, 77(2), 291-317. doi: doi.org/10.1215/00029831-77-2-291

This Article is brought to you for free and open access by the English Department at Digital Commons @ Trinity. It has been accepted for inclusion in English Faculty Research by an authorized administrator of Digital Commons @ Trinity. For more information, please contact jcostanz@trinity.edu. 


\section{W} volume of his Main Currents in American Thought, Vernon Parrington gave singular shape and force to an already established paradigm of the American nineteenth century as two discrete eras, hinged politically and culturally by the Civil War. After 1865, goes the familiar narrative, the Boston Brahmins and their "love of standards" were unseated by itinerant, gritty, self-made writers based in New York. ${ }^{1}$ For Parrington, this literary restaging of the American Revolution, in which Old World aristocratic power fell at the hands of an American populism, was best exemplified by Mark Twain - "a native writer thinking his own thoughts, using his own eyes, speaking his own dialect-everything European fallen away." ${ }^{2}$ This narrative, recycled by such esteemed scholars as William Charvat, Lewis Simpson, and Robert Spiller, has proved resilient during much of the twentieth century. ${ }^{3}$

The constituent parts of what became Parrington's narrative emerged decades before the end of the nineteenth century and were already in wide circulation by the 1880 s. Writers in the last quarter of the century habitually characterized themselves as vigorous and socially engaged and their literary forebears as affected aesthetes. Proponents of literary realism were especially partial to such rhetoric. William Dean Howells, for example, adapted Emerson's and Whitman's language to depict the new realist writer as one who necessarily "feels in every nerve the equality of things and the unity of men.... [I]t is his business to break the images of false gods and misshapen heroes, to take away the poor silly toys that many grown people would still like to play with." ${ }^{4}$ Similar depictions of the triumph of literary

American Literature, Volume 77, Number 2, June 2005. Copyright (C) 2005 by Duke University Press. 
vitality over effete tradition pervade periodicals of the time. But calls for realism actually constitute a relatively small proportion of this rhetoric of vitality, later instantiated in Parrington's characterization of the nineteenth century. ${ }^{5}$ As my essay will show, it was the international copyright movement-the extensive effort by diverse authors to generate public sympathy for a political campaign to improve legal protection of their rights-rather than a movement for literary realism that gave the most visible public expression to the idea of an aristocratic literary past in the United States. Situating the writer as a laborer, activists in the international copyright movement attempted to alter the widespread suspicion among Americans that literature was the realm of elite, privileged intellectuals with deeper ties to Europe than to the United States.

Between 1868 and 1891, writers across genres and even-in the terms of Parrington's periodization-literary periods participated in concentrated activism in support of international copyright legislation. American domestic copyright laws, instituted in 1790, preserved an author's rights only within the nation's boundaries and neither protected the American author from unauthorized reprinting abroad nor guarded foreign authors from piracy within the United States. Without international protection, English-language writers on both sides of the Atlantic complained of unauthorized reprintings not bound by law to pay royalties; of the frequency and license with which pirates made changes to their writings, even altering endings and adding characters; and of having their names attached to ghostwritten books. After a few false starts before the Civil War, the copyright movement emerged as a fully organized campaign just a few scant years after the war ended. Writers as diverse as Twain, Oliver Wendell Holmes, Henry James, E. P. Roe, and Edmund Stedman were active members of the American Copyright League, which counted over seven hundred members and presided over a lengthy campaign that included petitions, boycotts, and lobbying. Writers testified before Congress, contributed to public readings, signed petitions, and wrote scores of testimonials and essays describing the injustices of international piracy and detailing the moral, literary, and national benefits of international protection.

In a political movement composed largely of literary workerswriters, editors, publishers - it should come as no surprise that international copyright activists used the full range of print media at their 
disposal, from journalism to poetry. Sympathetic editors such as Richard Watson Gilder and R. R. Bowker made their periodicals-the Century and Publisher's Weekly, respectively-important vehicles for the international copyright movement, regularly reprinting articles published elsewhere and allotting space to open letters on the subject. Poets such as James Russell Lowell and James Herbert Morse turned their talents to the copyright cause and produced short, pithy verses that served as literary epigraphs to countless prose works addressing copyright. Critics such as Howells and George Lathrop used their columns to denounce piracy as the single greatest impediment to an American literature, and scores of other writers contributed their writings and celebrity by participating in literary readings sponsored by the American Copyright League. The writer and Presbyterian minister Henry Van Dyke even made use of his pulpit with the 1888 sermon "The National Sin of Literary Piracy," which was issued as a pamphlet that year by Scribner's and touted as the final moral word on the matter. ${ }^{6}$

Copyright supporters encountered significant obstacles to their efforts, from widespread public indifference to outright hostility from printers unions that feared legislation would result in reduced book production and shrinking employment. John Tebbel has argued that the primary obstacle to both public and Congressional interest was widespread suspicion of intellectual culture and literature, which were construed as antidemocratic traces of European aristocracy. ${ }^{7}$ Indeed, the language used on both sides of the debate substantiates Tebbel's claim. Although the International Typographical Union of North America eventually endorsed international legislation in the belief that it would increase domestic printing, it suspected the motives of American writers in waging this campaign; in its official journal, it suggested that writers neither needed the money they claimed to have lost through pirated copies nor had any real loyalty to the United States. ${ }^{8}$ Copyright activists bent over backward to counter this kind of suspicion. Local and national periodicals of the 1880 s are replete with attempts of American writers to raise public awareness and transform themselves in the public imagination from aristocrats to literary laborers on a par with other manual workers. It is in texts published in pursuit of this mission that the limits of Parrington's periodization come into view.

Examples of these texts abound in the 1880s and can be chosen 
virtually at random. In 1884, novelist J. W. De Forest signed a petition and attached a brief statement that was published, among other places, in the New York Times: "The American author is the only American laboring man who need not hope to live by his labor." 9 That same year the New York Times printed an open letter from novelist and editor Charles Dudley Warner to George Lathrop, Atlantic Monthly editor and realist critic (as well as Nathaniel Hawthorne's son-in-law), in which he declared that writers "are producers of valuable materials and things." ${ }^{10}$ In 1888 , Ohio Congregationalist minister and writer Washington Gladden directly compared the writer to the laborer: "[T]he author has the same right to the product of his mind that any workman has to the product of his hands." ${ }^{11}$ Even an opponent of international copyright, Philadelphia printer Roger Sherman, resorted to the language of labor in making his case, writing in an open letter to New York Congressman William Dorsheimer, which he published as a pamphlet in 1884: "If you accord to foreign authors the same right in this country that native writers possess, you tax the American citizen for something that he now possesses free, and you deprive the American artisan of the labor which he would be called to perform in the production of these books." ${ }^{12}$ Van Dyke freely used the language of labor in his sermon "The National Sin of Literary Piracy":

The value of any literary work depends upon the form which it gives to those ideas which belong to the common stock of truth. This form is the result of toil,- - toil which is more arduous and exhausting, toil which requires more patience and self-denial, toil which costs a large outlay of time and money to prepare for it, and a greater wear and tear of vital tissue to execute it, than perhaps any other kind of labor. The disembodied ideas are no man's property; but the embodied ideas, which have been brought into shape and order by the lonely worker in the sweat of his brain, are his own, just as much as the statue carved from the marble is the sculptor's own, just as much as the wheat cultivated in the field is the farmer's own. ${ }^{13}$

Van Dyke's weighted language shows significant energy and persistence in trying to alter the class status of literary labor.

While copyright advocates did not succeed in dispelling persistent public suspicion, their efforts overwhelmed the literary press with rhetoric depicting the writer as a laborer, an image designed to offset the lingering associations of authorship with aristocratic prerogative. 
The absorption of the language into literary history did not transpire because historians took at face value the claims of postwar writers to working-class kinship. If that had been the case, literary historians might have heeded the similar rhetoric of labor deployed by antebellum writers, recently documented by Michael Newbury. ${ }^{14}$ This rhetoric of literary labor had even played an active role in the prewar copyright movement, as manifest in John Jay's 1830 address before the House Committee on the Judiciary, in which he proclaimed that the writer "writes and he labors as assiduously as does the mechanic or husbandman." ${ }^{15}$ The rhetoric of authorial labor, then, was by no means specific to the postwar period or even to that phase of the copyright movement, but what made possible the canonization of this late-century rhetoric was an enthusiasm and appetite for historical narrative that pervaded not only the 1880 s but also the international copyright movement itself. ${ }^{16}$

The copyright movement was perhaps the most important institutional sponsor of the production of literary history in the period. Activists turned out countless works documenting injuries from piracy across American history. Publisher George Haven Putnam's 1891 collection The Question of Copyright contains no fewer than five separate histories of literary copyright, from antiquity to the late nineteenth century. Writers less inclined to produce full-length histories often peppered their prose on copyright with examples taken from the American literary past. Many of the era's most accomplished literary historians-including Thomas Lounsbury of Yale, Moses Coit Tyler of Cornell and the University of Michigan, and Charles Richardson of Dartmouth-were avowed sympathizers of and activists in the copyright movement. Other writers began their careers as literary historians by writing in support of international copyright. Brander Matthews, for example, was first a drama critic and playwright before he began to produce essays chronicling literary property rights. He eventually became one of the most successful and highly regarded American literary historians of the late nineteenth century, selling nearly 250,000 copies of his Introduction to the Study of American Literature (1896). The ties between literary history and the copyright movement were so pronounced that even works of literary history with no immediate service to the movement functioned as barely disguised copyright propaganda. For example, Lounsbury's 1882 biography of James Fenimore Cooper expressly discussed Cooper's long-standing 
problems with piracy, a discussion whose relevance to contemporary politics was made plain when Lounsbury interrupted his historical account to editorialize: "We may hope that we have gained since his time; but even at this day we have little to boast of." ${ }^{17}$ Similarly, Stedman and Ellen Hutchinson, editors of the extraordinary eleven-volume anthology Library of American Literature (1888-90), included alongside works of short fiction and poetry an essay on copyright by George Putnam, thus tacitly endorsing Putnam's argument while anointing the movement as an important event in American literary history.

The centrality of the production of literary history to the copyright movement merits some analysis. At the very least, historical narrative provided activists with a cover by which they were able to dodge political sniping. The copyright movement was exceedingly contentious, largely due to the outrage that often met authors' appeals; it was assumed that they were either already wealthy or came from the patrician class. The publication of any essay on authors' rights was sure to bring an outpouring of letters arguing opposing positions. Even activists in favor of international copyright were known to argue with each other, as the lengthy quarrel between Lounsbury and Henry C. Lea published in the New York Tribune in 1884 attests. ${ }^{18}$ But writing literary history seems to have provided copyright activists with a respite from such arguments and the threat of dueling in the press. In fact, activists quickly exhausted argument as a vehicle for the movement, so there are relatively few solely argumentative writings in the copyright archives. Instead, the vast majority of work published on the copyright question in the 1880s is limited to the recitation of data: histories of copyright, myriad reprints of the texts of copyright bills, and bibliographies of publications on copyright. These works allowed activists to keep the copyright movement in the public eye while avoiding the inevitable disagreements that threatened to make their efforts seem subjective and morally indefinite. This is not to suggest that the many literary histories published in support of copyright are without argument; rather, as one of the strategies by which activists were able to circumvent bitter public quarrels, the medium of literary history allowed argument to pass under the radar of detractors with ready pens.

This collateral benefit aside, literary history chiefly allowed writers to circumvent the ire of a public unsympathetic to the financial pleas of a constituency they believed to be aristocratic. Literary history, that 
is, proved instrumental in bridging class divisions that had interfered with public support of copyright protections for so long. Brander Matthews's telling, if disingenuous, explanation for the prominence of literary history in copyright literature neatly illustrates the usefulness of historical narration in this context:

The struggle to secure the protection of our laws for literary property produced by citizens of foreign countries has been long and wearisome. To some it may seem fruitless. An ocean of ink has been spilt and a myriad of speeches have been made; and yet there are no positive results set down in black and white in the Revised Statutes of the United States. But the best cure for pessimism is to look back down the past, and to take exact account of the progress already made. This examination reveals solid grounds for encouragement in the future. The labor spent, although often misdirected, has not been in vain. Something has been gained..$^{19}$

Matthews attributes the rise of literary histories to the need to take stock of past successes in order to retain optimism amid unremitting obstacles. But his designation here of the "citizens of foreign countries" as the primary beneficiaries of copyright activism reveals the latent motives of literary history hiding in plain sight.

International copyright promised to protect not only American writers from piracy abroad but also foreign writers from piracy within the United States, where many imprints specialized in cheap reprints of foreign works, usually British ones. Copyright activists often discussed copyright within a moral and legal framework that allowed them to address piracy without the specificity of authorial nationality. Although the interests of foreign writers pirated in the United States did occasionally appear as terms of debate, copyright activists generally appointed American writers as unambiguous victims of a British publishing industry that belittled American literature even as it brazenly pirated it. In an interesting turn to the foreign author as the primary beneficiary of copyright law, Matthews displaces the onus of piracy - and the benefits of copyright law - away from himself and his peers. Matthews's own well-known wealth and aristocratic lineage tacitly underlie his decision to invoke the foreign writer, enabling him to deflect the criticism of self-interest leveled by skeptics and to reconstitute himself and the movement as altruists campaigning for the sake of others. It is fitting that Matthews would attempt to imbue the copy- 
right movement with selflessness in a context that largely served that very purpose for copyright activists: literary history allowed activists to document the injuries of piracy without making themselves open to accusations of selfishness and money-grubbing.

Matthews's widely reprinted essay "American Authors and British Pirates" offers a typical example. First published in the New Princeton Review in 1887 and issued as a pamphlet two years later by the American Copyright League, the essay responds to British protestations of innocence with a meticulous catalog of pirated American books for sale in Britain at the time. In opting for hard data over subjective argument, this essay conveys the widespread desire of activists to stay above the fray by allowing evidence to stand alone and speak for itself. Before beginning this inventory, Matthews briefly discusses the effects of piracy on earlier writers such as Cooper, Hawthorne, and Longfellow, substantiating his claims with evidence culled from biographies, letters, and diaries attesting to the wrongs these writers endured. This prefatory narration of the literary past primes readers to be receptive and sympathetic to the list that will follow, for it draws on a presumed affection for writers whose status was in the process of being fortified by the many literary histories published in the era. Matthews uses literary history to waylay accusations of self-absorption and envelop the movement with dutiful piety and filial respect. The result is the constitution of copyright activists as literary avengers redressing the wrongs endured by those who had been unable to act.

No figure of literary history appeared more frequently in this setting than Washington Irving, whose status as the nation's first internationally recognized writer made him not only central to any American literary history but also a suitable case study of copyright infringement, as his transatlantic celebrity made him particularly vulnerable to foreign piracy. His centrality to the copyright movement may have been facilitated also by the waning reputation and aristocratic pretensions of Cooper, Irving's most famous colleague in piratical injury in early American letters. In the preface to his collection The Question of Copyright, Putnam interrupts his discussion of the general inadequacy of copyright law to relate the bitter circumstances surrounding Irving's patrimony after his death. The brief extension of copyright after an author's death had made Irving "unable to insure for his nieces (his adopted children) the provision which they needed, and which a continued copyright in their uncle's works would have 
secured for them." ${ }^{20}$ Putnam's heartrending account of displaced bequests and disinherited daughters reduces the complex matter of copyright to a simple moral calculus: copyright is necessary to protect the vulnerable and powerless, an argument that directly counters the arguments of those critics who intertwined authorship with hereditary power. ${ }^{21}$

It is impossible to reconstruct the reception of such rhetoric, especially because copyright supporters controlled literary media and closely monitored the ways in which copyright was handled in the press. However, one must not discount the influence of the then quasiacademic genre of literary history in imbuing copyright rhetoric with legitimacy and erudition. Moreover, it bears noting that the authorsor circulators-of such rhetoric were themselves reputable writers, critics, and scholars whose reputations also helped lend it credence. But altering public perception of literary work required the proliferation of rhetoric not only about labor but also about the aristocrat, the apparition that has long stalked literary work in the West and that late-century American writers were at pains to cast off. And it is in pursuit of this aim that the rhetoric of international copyright mediated uneasily between the literary present, in its struggle to affirm authorial labor, and the literary past, in both its narration of literary history and its management of the aristocracy. I do not want to suggest that this occurred with the production of literary histories that inflected the American literary past with elitism and privilege. (On the contrary, literary historians-Matthews among them-took pains to depict antebellum writers such as Hawthorne as working men, establishing their character by documenting the financial burdens they endured.) I argue, instead, that the periodization of the nineteenth century was made possible by the entanglement of literary history with political history. The conflict at the core of the international copyright movement indeed pit the aristocrat against the populist, but in their struggle to divest themselves of the taint of aristocracy, copyright advocates manufactured narratives that displaced the immediate political and literary context of the copyright dispute onto the literary past, as reiterated by Parrington's periodization of the nineteenth century.

For explication, I turn to an example taken from early in the postCivil War copyright movement, with the founding of the International Copyright Association, a precursor to the American Copyright 
League that disbanded in the wave of belt-tightening after the financial panic of 1873. At the first meeting of the Association, Presbyterian minister Samuel Irenaeus Prime-a founder and editor of the New-York Observer and manager of the "Editor's Drawer" column in Harper's Magazine - proclaimed the movement "a demand for justice. It is not asking for privileges; it is the assertion of rights." ${ }^{22}$ On the heels of this announcement, Prime tells a story meant to illustrate these wider political aims:

In the year 1784, the year after our National Independence was recognized by treaty with Great Britain, an English publisher seized upon Morse's Geography, an American copyright work of great literary and pecuniary value, and published it without recognition of the rights of the author, and without making him the least compensation. That system of piracy thus begun has been relentlessly pursued by the British, with a disregard for our rights which has justified the remonstrances of authors and publishers, and which they have bitterly and often complained of, these many years. ${ }^{23}$

Prime's story of the first geography published in the United States by an American, Jedidiah Moore's Geography Made Easy (1784), gives way to a larger narrative of British tyranny. Situated in the aftermath of the American Revolution, this story treats the piracy of Moore's geography as the founding moment of a long-standing practice in which the British contravene American political as well as literary sovereignty. Within the logic of Prime's narrative, it is important that Moore's geography was published in the wake of the American Revolution, for he regards Moore's text as the cultural fruit of that political rupture. Prime also sees in this piracy, however, a continuity of British tyranny, although it has evolved from political to cultural and literary tyranny. British oppression endures in the literary arena, and the international copyright movement emerges as a modern version of the American Revolution in its pursuit of independence from Britain. Prime's rendering of the current dispute as an atavistic extension of the American Revolution is designed to assure activists of the successful conclusion to this most recent quarrel.

Prime's account points to the primary vehicle by which copyright advocates were able to affix aristocracy to the American literary past: the centrality of Britain and transatlantic literary relations in the copyright movement. Despite the movement's avowed internationalism, 
England and Scotland were its principal targets, as shared language made piracy easy and economical for British and American publishers alike. Hostilities toward Britain overwhelmed the movement; the literary histories produced in support of copyright were, like Matthews's essay "American Authors and British Pirates," generally limited to incidents of British piracy endured by American writers. The very complicated matter of international copyright, which entangled international relations with class-based disputes between workers and authors in the publishing industry, was reduced to a transatlantic quarrel within what Matthews, borrowing from James Russell Lowell, called the "community of blood, of law, of language, and of books existing between Great Britain and the United States." ${ }^{24}$ In a distillation that essentially revised Prime's account, F. A. P. Barnard, then president of Columbia University, wrote: "Between Great Britain and the United States there has been a war in the literary field of a century's standing, signalized by incessant acts of pirateering on both sides." 25

Isolating Britain as the principal villain was astute, for it allowed copyright activists to revise somewhat the terms of authorship already in circulation. Eager to relieve themselves from the freight of aristocracy, late-nineteenth-century writers were able to map the populistaristocrat dyad onto their literary grievances with Britain, whose prominent aristocracy made it an easy target. In depicting themselves in conflict with Britain, American writers were able to reposition themselves in this dyad as the abused victims of a literary aristocracy. In 1890, the New York Times published an editorial on copyright containing this rhetorical move:

In American communities there is a well-grounded tendency to regard a man who is merely the heir to a fortune as one who has never endured the tests of labor and hardship, in contradistinction to the feeling in Europe, which makes people ridicule and belittle the "self-made" man, whether or not his manners are such as deserve it. Authors are essentially self-made men, in the best sense of that abused term, and as such are often subject to a certain coolness on the part of fashionable folk at home and abroad, for the latter are taught to value most the descendents of ancestors raised by wealth above the struggle for existence. ${ }^{26}$

Britain and the United States stand in clear opposition here in their respective attitudes toward pedigree, and the article uses British rev- 
erence for aristocratic lineage as an explanation for their ill-treatment of American authors, especially in copyright matters. With the disingenuous announcement that "authors are essentially self-made men," the article is able to make writers the apotheosis of the American values of self-reliance and self-invention and Britain the center of aristocratic operations. And this move leads inexorably to the alignment of copyright with democracy, as with Matthews's observation that “[i]t is pleasant for us Americans to know that this first feeble acknowledgment of copyright was made by a republic" in Venice in $1469 .{ }^{27}$ Matthews saw more than coincidence in the simultaneous emergence of copyright and the rise of democracy in the English-speaking world, for, he argued, the legal protection of authorship is an indispensable step in the legal enfranchisement of all people. Twain, an avid copyright activist, concurred in A Connecticut Yankee in King Arthur's Court (1889), where Hank Morgan, a Connecticut foreman displaced to the sixth century, begins his campaign to dismantle Camelot's aristocracy by establishing intellectual property laws: " $[\mathrm{F}]$ or I knew that a country without a patent office and good patent laws was just a crab, and couldn't travel any way but sideways and backwards." 28

High-profile tours of the United States by British writers complicated Britain's public image within the copyright movement. Matthew Arnold, Charles Dickens, and Anthony Trollope were among the outspoken advocates of an Anglo-American international copyright agreement and all used their tours of the United States to generate interest among Americans. ${ }^{29}$ Dickens undertook two tours, the first in 1842 and the second immediately following the American Civil War in 1867 , and both tours have been credited with invigorating the American copyright movement with his explicit, if awkwardly received, exhortation on the matter. ${ }^{30}$ These tours produced mixed feelings among Americans, who were disappointed by what they perceived as ingratitude, rudeness, and explicit cultural criticism from their guests. When Dickens famously addressed international copyright, he outraged Americans with his accusations of piracy and requests for remuneration, thereby consolidating copyright activism with greed, ingratitude, and anti-Americanism in the American consciousness, associations that thwarted later American copyright enthusiasts.

Although Dickens has been credited with launching the postwar copyright movement, Arnold cast the longer shadow in providing an unwitting vehicle by which late-nineteenth-century activists were 
able to define themselves as populists and defenders of American democracy against British cultural elitism. In advocating literature as "simply trying to see things as they are," Arnold found a receptive audience among post-Civil War American writers sympathetic to the realist idiom, among them Matthews, Howells, and Sarah Orne Jewett. ${ }^{31}$ Although he frequently criticized the British hereditary aristocracy, Arnold advocated instead a kind of intellectual aristocracy composed of writers and other intellectuals in the hope that it would elevate the national tone, a vision that comported with the ambitions of American realists such as Howells and Frank Norris. At times, Arnold sounded virtually Emersonian in decrying the desiccation of literary culture and the ascendance of "something bookish, pedantic, and futile" in the public perception of "the word culture." Culture, he continued, is "great help out of our present difficulties. . . , turning a stream of fresh and free thought upon our stock notions and habits, which we now follow staunchly but mechanically." ${ }^{2}$ Although a similar belief led Emerson to anticipate a new age in American life and to elevate the plebeian as fit aesthetic and philosophical material, it caused Arnold to criticize the United States for the dominance of the very element that Emerson had exalted. Arnold frowned on the American emphasis on work and its accompanying anti-intellectualism, and although he reified the terms that were at the center of international copyright rhetoric, Arnold indirectly cast aspersions on authorial efforts to pander to these aspects of American culture. It is no surprise, then, that despite the fact that many American writers were sympathetic to some of Arnold's beliefs, they turned against him during his tour, taken during the peak of copyright activism in 1883 and 1884, portraying him as the embodiment of British aristocratic elitism.

Arnold's fraught relationship with the United States was propelled by numerous missteps in which his remarks about American antiintellectualism were roundly denounced by those American writers who most suffered from this insularity. His position on copyright didn't help matters, as he interpreted the national apathy toward international copyright as evidence of American philistinism, sparking the ire of copyright activists intent on aligning themselves with the very population sector he denounced. ${ }^{33}$ American writers of varying social positions recoiled at Arnold's manner, which was perceived as anti-American and condescending. Just as self-made writers Howells, 
Twain, and Whitman flexed their populist muscles in response to Arnold's behavioral signifiers of aristocracy, Lowell and Thomas Wentworth Higginson charged Arnold with an aristocratic bias in his criticisms of the United States. Coming from two Boston Brahmins with elite lineage and concerted ties to England (Lowell was at that time American diplomatic liaison to Britain), such claims seem like conspicuous attempts to transfer the onus of Anglophilic snobbery from themselves to Arnold. ${ }^{34}$ In fact, Higginson and Lowell exaggerated Arnold's aristocratic sympathies, although Arnold had consistently lamented the power and influence of the British aristocratic classes, which in 1869 he characterized as "unintelligent" and out of touch. ${ }^{35}$ Arnold responded to Higginson and Lowell with the 1882 essay "A Word about America," in which he claimed to share Lowell's hopes that American culture might produce an environment receptive to "culture" and populated by judicious consumers. He disavowed aristocratic biases, claiming that "if American democracy gives this, Mr. Lowell may rely upon it that no narrow Anglicism shall prevent my doing homage to American democracy." 36

Arnold made several more awkward missteps that allowed American writers to regard him as the embodiment of aristocratic snobbery and themselves as injured populists. In 1884, he unwisely delivered a lecture in which he announced that Emerson lacked greatness as a poet, writer, and philosopher. Outrage and controversy immediately followed, especially in the Boston press, and his criticisms were widely distorted to constitute evidence of Arnold's anti-American irreverence and snobbery. ${ }^{37}$ Upon his return from the U.S. tour, Arnold published several more pieces that aggravated already hostile relations, including "A Word More about America" (1885), composed in direct response to his trip, and "Civilisation in the United States" (1888), which was published shortly before his death and became infamous for his statement that the United States failed to hold his interest. One reader, Civil War general James Fry, responded in the North American Review: "Surely we have been interesting to British Sovereigns from Victoria all the way back to George the Third, and to British statesmen from Gladstone to Pitt; and it is beyond dispute that we have proved interesting to the British Army and Navy whenever we have met them." ${ }^{38}$ Like copyright advocates, Fry narrated past American military engagements with Britain to resolve present transatlantic difficulties. But the episode that caused the greatest out- 
cry against Arnold occurred in 1887, when he gave Ulysses Grant's memoir an unfavorable review and took potshots at Grant's grammar, which inflamed American indignation in seeing their Civil War hero humiliated by a critic they already regarded as an aristocratic snob. Fry again resorted to military language in the North American Review, pronouncing Arnold an "enemy." 39 As publisher of Grant's enormously successful memoir, Twain went immediately on the defensive with an address given to a military audience, Connecticut's Army and Navy Club, in which he subjected Arnold's review to the same grammatical scrutiny. ${ }^{40}$

It is plain that the centrality of Britain in the American literary imagination of the 1880 s allowed copyright enthusiasts to position themselves as populists locked in struggle with British hegemony. However, what has proved to be especially important and enduring is the incorporation of this ploy into a historical narrative of the nineteenth century promoted by Parrington and others. Indeed, the narration and reperformance of American victory over Britain circulated by copyright activists is, at its core, the same story as Parrington's periodization. Both narratives position a culture predicated on pedigree and Old World sympathies in conflict with a culture characterized by self-invention and self-creation, and both narrate the demise of lineage in favor of meritocracy, the decline of aristocracy in favor of populism. The discourse of Anglo-American political history that made the dyad of populist-aristocrat particularly weighty in the late century figures as an early avatar of the narrative of democratic ascendancy at the core of the periodization of the nineteenth century. Vital to the imbrication of these two narratives is a consciousness of the past, which offered a rubric for disentangling the untidy relations within the literary circum-atlantic and leaving late-nineteenth-century American writers free to define themselves as independent of these transnational, transhistorical relationships. Despite the martial rhetoric freely bandied about, Britain and the United States enjoyed stable political relations in the late nineteenth century and were mutually dependent trade partners; the late-eighteenth-century military engagements that figured in metaphors of the literary transatlantic were already swaddled in nostalgia and remoteness. ${ }^{41}$ The pastness that encircled this metaphorical conceit became the vessel that contained the Anglicized Old World, which had long fueled American suspicions of authorship. To the advantage of late-century writers, the past became the site onto 
which a literary aristocracy was displaced, as narrated by the periodization of the nineteenth century.

Coiled beneath the depiction of the past as a ferment of aristocratic sensibilities and sympathies lies one of the central arguments used by copyright activists. Attempting to communicate the wider consequences of pervasive transatlantic piracy, writers contended that the surfeit of cheap pirated editions of British literature had overwhelmed American literature, making it impossible for American writers to compete with lower-priced texts by better-known British writers. In an 1890 report to the House Committee on Patents, Congressman W. E. Simonds of Connecticut argued: "American authors are subjected to untrammeled competition with English authors who do not receive a farthing for their labor." ${ }^{2}$ If it weren't bad enough that Britons had shamelessly pirated American writers, those writers' victimization at the hands of American publishers had led to their being squeezed out of their own literary home market. "[T]he system is dwarfing American literature," wrote journalist and minister Lyman Abbott; and publisher Henry Holt, in testimony before the Senate, concurred: "It is the question whether we are to continue to have an American literature-for, as you all know, American literature is languishing even now-the question whether ... we are to derive our ways of thinking, our ideal of life and politics, from alien, unsympathetic sources." ${ }^{43}$ That same year, Holt responded to Philadelphia printer and copyright opponent Roger Sherman by arguing that "the competition of foreign literature whose authors are not paid is making it impossible for new authors to get a foothold, or for old ones to get proper pay." ${ }^{44}$ Copyright prose is replete with testimonies and arguments declaring that the wide circulation of cheap British editions had instilled in readers an appetite for British literature and, in Twain's words, "an unhealthy fascination for foreign life, with its dukes and earls and kings, its fuss and feathers, its graceful immoralities, its sugar-coated injustice and oppressions." ${ }^{45}$ The popularity of pirated novels among American readers was played by copyright activists as the initial steps in a retrogressive return of the United States to a British colony, in which American citizens absorb and imitate the manners culled from British literature. "It is not wholesome," Matthews writes, "nor a good augury for the future of the American people, that the books easiest to get, and therefore most widely read, should be written wholly by foreigners, and chiefly by Englishmen, who can- 
not help accepting and describing the surviving results of feudalism and the social inequalities we tried to do away with one hundred and twelve years ago." ${ }^{46}$ While realists such as Howells deployed similar rhetoric in an attempt to stir public interest in realist and localcolor fiction, the immediate political context of such language posited international copyright as an agency of cultural immigration, barring unwanted foreign influences at the border and protecting the integrity of American culture and literature.

The periodization of the first half of the nineteenth century depends upon this narrative of imitation and assimilation. Unidirectional transatlantic influence has come to be a mainstay of American literary history in the works of critics such as Aubert Clark and Robert Weisbuch, who have verified copyright activists' claim that the absence of international protection produced widespread imitation among American writers, if not readers. In the words of Van Dyke, free literary piracy across the Atlantic produced American literary "mimicry of English models" and a culture of literary imitativeness among writers desperate to compete with the cheap, pirated British novels favored by readers. ${ }^{47}$ The belief that American writers have had to beat British writers by joining (and imitating) them was so central to the copyright debate that even opponents of copyright, such as Henry Carey, put the lack of originality in American literature at the center of their argument to claim the inevitability of imitation and therefore the injustice of copyrighting ideas. The presumed imitativeness of American literature has long been believed to be a condition of the piratical waters of nineteenth-century, English-language literature, but what's especially important about this claim is its legacy in the periodization of the century. While we may debate the legitimacy of the characterization of the first half of the century as aristocratic in its allegiances, the influence of British literature on that time period endures as accepted wisdom, influence made possible by copyright loopholes. Underlying the narration of an aristocratic literary past are the consequences of piracy for struggling American writers forced to compete with unpaid British labor. The detection of an anglicized Old World in the American literary past may describe less the dominance of pedigreed Boston Brahmins than the conditions of literary success in a market that necessitated the imitation of British fiction.

An additional variable in the construction of an aristocratic American literary past is the strong presence of James Russell Lowell in the 
copyright movement. Although he continued to publish after the war, Lowell found his greatest success in the antebellum era with The Biglow Papers and A Fable for Critics (both 1848) and was an important member of the popular grouping of Boston-area writers known as the Fireside Poets. A descendent of an illustrious Puritan family, a Harvard graduate and holder of the Smith Professorship of Modern Languages at Harvard, as well as American ambassador to England during the first half of the 1880s, Lowell typified the pedigreed Boston gentleman firmly associated by literary historians with the antebellum period. Lowell's language reveals the depth of his own literary elitism: he dubbed literary achievement the "American Parnassus" and called the literati the "Elect," a term taken directly from the religious doctrine of his Puritan ancestors that suggests the preordination of literary success. ${ }^{48}$ In a letter to Howells, Lowell voiced anxiety about the decline of the literary gentility with which he and his cohort would be so firmly associated: "The danger of our literature ... seems to me to be lawlessness \& want of scholarly refinement. This is the rock I see ahead just now, \& I fear we may go to pieces on it if we don't look sharp." ${ }^{49}$

Part of Lowell's importance in the copyright movement stemmed from his venerability and his association with the Puritans and the antebellum era, which made him a cynosure of copyright and guardian of the movement's respectability. His august status led to his appointment to the post of American minister to England, a position that lacked genuine diplomatic importance but allowed him to serve as the respectable face of American literature before British writers hostile toward the copyright-resistant American government and the brazenly piratical publishing industry. ${ }^{50}$ Lowell was an important weapon in helping the movement retain its tone of civility. An off-hand quatrain sent to the Century in response to a questionnaire from editor Richard Watson Gilder was widely reprinted, as was his testimony before Congress. In particular, one pithy comment from that testimony-"there is one book better than a cheap book, and that is a book honestly come by"-became a veritable maxim of the movement, and his words were received like the wisdom of a sage or church elder..$^{51}$

It is important that Lowell was president of the American Copyright League when the copyright law was finally passed in 1891 . Lowell had been unable to attend any of the celebrations held by the League and died shortly thereafter. Despite his absence, however, Lowell hovered 
over the League's 1891 banquet through numerous toasts to his health and readings of his various epigrams as well as his apologetic letter explaining his absence. Transcripts and published accounts of the banquet communicate a solemn tone, as if the gathered party sensed Lowell's imminent death. The celebration of the passing of the law doubled as a commemoration of the rapidly passing life of Lowell; in effect, the celebration of this event in American legislative history solidified the passing of Lowell's generation and concluded the movement that produced the language by which Lowell and his peers would be remembered. With his death, the American aristocratic literary regime receded decisively into the past, in conformity with the periodized narrative already in circulation and at the end of the movement that produced that narrative.

It bears remarking that the subterranean undercurrents of the aristocratic literary past delimited by American literary history were by no means confined to Anglo-American relations; rather, the very concept of an aristocratic American past summons not only transatlantic literary traffic but also the more recent struggles with another aristocratic opponent, albeit one internal to the United States. In short, superimposed on the periodization of the nineteenth century are the political and cultural conflicts that resulted in the American Civil War, and Arnold's comments about Grant and the response they elicited laid bare the interconnection between the recent and the more distant past. His comments rekindled American memories of the British position in the Civil War, which was decidedly pro-South and aristocratic. The cultural similarities between the American South and Europe were already common knowledge. As early as 1835, Alexis de Tocqueville had commented on the resemblance, and in 1883, the same year as Arnold's tour, Twain expounded on Southern aristocratic pretensions in Life on the Mississippi. Twain's famous belief that the popularity of Walter Scott's novels in the American South had fueled aristocratic sensibilities and indirectly led to the Civil War merits a reconsideration within the context of international copyright, for the wide circulation of these British novels can be attributed to ubiquitous piracy and cheap editions.

In criticizing Grant's grammar, Arnold became a representative of two different enemies of New England and the Mid-Atlantic, the geographical regions that, in producing the nation's principal literary historians, became the nominal representative of the nation as a whole. 
Arnold became, that is, a representative of two aristocratic foes, Britain and the American South. Howells's reflections on Arnold's death in 1888 illustrate the unconscious intermingling of the two in the late nineteenth century. Though Howells reluctantly conceded the legitimacy of Arnold's criticisms of American culture, he countered with a list of American accomplishments, among them the names of numerous Americans he regarded as exemplars of national character: Lincoln, Grant, Emerson, Stowe, and John Brown. ${ }^{52}$ This is an important and telling list of Americans, as they all played central roles in determining Northern beliefs and goals in the Civil War. Howells's list of great Americans indirectly communicates the spectral presence of the American Civil War-and the North's position in it-in his thinking about Arnold and the turmoil with Britain that Arnold came to represent. A British attack leads him to a retort more appropriate for a different historical event.

The entanglement of the American Revolution and Civil War was enabled by the concerted cultural and political ties between both enemies of the American North-Britain and the South. British support of the Confederacy resonated with late-century writers. Just four years after the close of the war, Lowell published the suggestively titled essay "On a Certain Condescension in Foreigners," in which he made sense of British support for the South. He recounted a conversation during the war with an English "gentleman of the highest description" who paid him a visit to communicate "how entirely he sympathized with the Confederates, and how sure he felt that we could never subdue them,- 'they were the gentlemen of the country, you know." "53 In his analysis of Anglo-American literary relations during the nineteenth century, Clarence Gohdes attests to the shared class interests and sympathies that led to widespread support among upper-class Britons for the American South, who saw the imminent demolition of the feudal economy and aristocratic social structures from which they had benefited in their own country. ${ }^{54}$ Cultural ties, that is, produced political ties.

Copyright activists also compared their campaign to the Civil War, a rhetorical comparison made possible in part by the reappearance of discussion about tariffs in copyright debate. Popularly called the "knowledge tax" on transported books, the tariff figured prominently in copyright discussion, even though it had no direct connection to international copyright. Putnam even explicitly stated that the debate 
about the tariff had sufficiently "hampered" the copyright movement and distracted it from its stated purpose ${ }^{55}$ Regardless, the revival of discussion about tariffs and protectionists in this context generated a readiness to compare this literary struggle to the Civil War, specifically in the explicit comparison of piracy to slavery on the grounds that both enterprises involved protested transport of commodities across the Atlantic..$^{56}$ In an 1887 address, Lowell directly compared the pirated book to the smuggled slave, and that same year Howells wrote: "[T]he American nation ... willfully perpetuates an abuse which in a small way is morally worse than slavery.... Slavery compelled a man's labor, but it gave him in return food, shelter, and clothing, such as they were; literary piracy seizes the fruits of a man's labor, and gives him absolutely nothing in return." ${ }^{77}$ Although offensive in its description of slavery and amplification of piracy, this passage condenses and concentrates the terms central to the periodization of the nineteenth century, for it uses the slave both to allude to the aristocratic economy of the past and to depict the late-century writer as a laborer ${ }^{58}$

With the passage of the copyright bill, activists celebrated not only the legal dismantling of transatlantic piracy but also the fulfillment of copyright narratives of democratic ascent over Old World aristocracies. During the $1880 \mathrm{~s}$, copyright enthusiasts pointed toward the vast popularity of pirated British texts and the imitativeness of American fiction to presage the total collapse of American cultural, if not political, independence from Britain; the absence of copyright law threatened to return the United States to a British cultural colony, if not a political one. Matthews pointed to the Britannia Series in England, composed entirely of American pirated texts, to show the imminence of this hostile cultural takeover ${ }^{59}$ Once the bill was passed, however, its supporters exchanged the places of the two nations to announce the triumphant success of democracy. During his toast at the celebratory banquet, Stedman, then vice president of the American Copyright League, proclaimed: "All British authors are now American authors. The old toast about the commonwealth of those who inherit the language of Shakespeare and Bacon and Milton at last means something." ${ }^{60}$ Although the United States lagged considerably behind Britain, and Europe more generally, in its enactment of international copyright laws, its supporters interpreted the passage of the 1891 law as the spread of American values eastward across the Atlantic. In being forced to honor the property rights of American literary 
laborers, the aristocrat had been vanquished and Americanized. Stedman described the successes of the law in language that exposes the latent motives of the copyright movement, concealed beneath the disguise of literary history and rhetoric: "All will now compete on nearly equal terms." ${ }^{61}$ American writers, that is, would now have a fair position in the English-language literary market. This drive for position in the transatlantic market is the hidden history of the periodization of the nineteenth century.

Trinity University

\section{Notes}

I wish to thank Michael A. Elliott, Judith L. Fisher, Larry Kutchen, and Char Miller for their generous responses and astute suggestions. The research for this essay was partially funded by a fellowship from the Houghton Library, Harvard University, and its writing was financed by a Tom and Mary Turner Faculty Fellowship granted by Trinity University.

1 Vernon L. Parrington, The Beginnings of Critical Realism in America, 1860-1920, vol. 3 of Main Currents in American Thought (New York: Harcourt, Brace, 1930), 4. Of Parrington's pervasive influence, Lionel Trilling wrote in 1953: "His ideas are now the accepted ones wherever the college course in American literature is given by a teacher who conceives himself to be opposed to the genteel and the academic and in alliance with the vigorous and the actual" ("Reality in America," The Liberal Imagination: Essays on Literature and Society [New York: Anchor, 1953], 1).

2 Parrington, The Beginnings of Critical Realism, 86. In its reliance on associative geography, this qualitative periodization oversimplifies the literary climate in both halves of the American nineteenth century, and the bifurcation itself misrepresents the actual dispersion of literary culture. Placing Harvard-educated men at the center of power in the antebellum era obscures the many prominent women authors whose writings challenged the prerogatives of privilege. Casting the aristocrat as the important literary figure before the Civil War despite the early emergence of literary cultures in Connecticut, New York, and Philadelphia fails to consider the degree to which many writers before Twain-Emerson, Hawthorne, Thoreau, Whitman-revolted as early as the 1830s against the dominance of a hereditary literary class that displayed its pedigree with devotion to European letters. Also passed over are the many antebellum writers who remained popular and productive far beyond the temporal limits assigned to them, yet this periodized narrative would have us believe that the rise of self-made writers without formal education, such 
as Mark Twain, was concomitant with the convenient disappearance of their predecessors.

3 Many texts rework or build upon the foundation of Parrington's argument; classic examples include William Charvat, The Profession of Authorship in America, 1800-1870: The Papers of William Charvat, ed. Matthew J. Bruccoli (New York: Columbia Univ. Press, 1992); Lewis P. Simpson, The Man of Letters in New England and the South: Essays on the History of the Literary Vocation in America (Baton Rouge: Louisiana State Univ. Press, 1973); and Robert E. Spiller et al., Literary History of the United States (New York: Macmillan, 1948).

4 William Dean Howells, “Stevenson's and Hawthorne's Romances; Balzac; Realism," Selected Literary Criticism, 1886-1897, 3 vols. (Bloomington: Indiana Univ. Press, 1993), 2:21.

5 In Parrington's periodization, authorial pedigree is an index to political and literary affiliation, but one has only to read Howells's columns and reviews in Harper's to recognize that a late-century writer's undistinguished parentage by no means indicates a diminishment in the "love of standards" attributed to antebellum New England. Similarly, the pedigree of many writers before and after the Civil War fails to conform to the terms offered by Parrington's narrative, calling into question the insistence on class as a way to organize the literary nineteenth century. For examinations of the marked conservatism of many late-century writers bundled together under the term literary populism, see Michael Davitt Bell, The Problem of American Realism: Studies in the Cultural History of a Literary Idea (Chicago: Univ. of Chicago Press, 1993); Nancy Glazener, Reading for Realism: The History of a U.S. Literary Institution, 1850-1910 (Durham, N.C.: Duke Univ. Press, 1997); and Amy Kaplan, The Social Construction of American Realism (Chicago: Univ. of Chicago Press, 1988).

6 See “The Author's Rights," New York Times, 9 January 1888, 8.

7 See John William Tebbel, The Expansion of an Industry, 1865-1919, vol. 2 of $A$ History of Book Publishing in the United States (New York: Bowker, 1975), 640.

8 See, for example, the editorial in Journal of the International Typographical Union of North America, 15 January 1890, 9.

9 J. W. De Forest, “A Novelist's Opinion of Copyright,” New York Times, 24 February 1884.

10 Charles Dudley Warner, letter to the editor, New York Times, 13 January 1884; reprinted in Publishers Weekly, 19 January 1884, 60-61.

11 Washington Gladden, “Open Letters,” Century, July 1888, 474.

12 Roger Sherman, International Copyright. An Open Letter (Philadelphia: Sherman and Company, 1884), 4.

13 Henry Van Dyke, The National Sin of Literary Piracy (New York: Scribner's, 1888), 12. 
14 See Michael Newbury, Figuring Authorship in Antebellum America (Stanford, Calif.: Stanford Univ. Press, 1997).

15 John Jay, International Copyright: Memorials of John Jay and of William C. Bryant and Others, in Favor of an International Copyright Law (Washington, D.C.: Tippin and Streeper, 1848), 2.

16 Despite the fact that American literature was still largely untaught in the nation's schools, the 1880s saw a proliferation of American literary histories, attributable to numerous stimuli. The nation celebrated many national centenaries commemorating, for example, the ratification of the Constitution and Washington's inauguration, which spawned a host of backward-looking assessments surveying the nation's brief history. No aspect of American culture has been used more than its literature as an index of the nation's vitality, success, and growth, and so it is no coincidence that these many national centenary celebrations gave rise to a widespread desire to survey the history of American literature as a way of assessing the nation itself. Furthermore, the late nineteenth century witnessed for the first time a transfer of power from one literary generation to another, marked by the many funerals and gala dinners in honor of literary éminences grises such as Emerson, Longfellow, Lowell, and Whittier. These events produced countless valedictory celebrations of the literary past that created an environment sympathetic to literary retrospection, and many of these obituaries found their way into literary histories published soon after.

17 Thomas R. Lounsbury, James Fenimore Cooper (1882; reprint, Detroit: Gale Research, 1968), 166.

18 See letters to the editor, New York Tribune, 18 and 25 February 1884; and 8 March 1884.

19 Brander Matthews, in “Open Letters," Century, July 1885, 488; quoted in Aubert J. Clark, The Movement for International Copyright in NineteenthCentury America (Washington, D.C.: Catholic University of America, 1960), 148.

20 George Haven Putnam, preface to The Question of Copyright. A Summary of the Copyright Laws at Present in Force in the Chief Countries in the World, ed. George Haven Putnam (New York: Putnam, 1891), viii.

21 Putnam's inclusion of Irving's plight as literary historical evidence of the wrongs of copyright infringement is complicated by Putnam's involvement as plaintiff in a high-profile lawsuit, Putnam v. Pollard, in which he, as Irving's long-time publisher, challenged a reprinting of Irving's works without the consent of Irving's nieces. In telling this story of Irving's thwarted legacy, Putnam attempts to defuse accusations of self-interest by turning to the literary past but substantiates those charges by exposing the motives that underlay both his support of copyright and his account of literary history.

22 “Speech of S. Irenaeus Prime," in International Copyright: Meeting of 
Authors and Publishers, at the Rooms of the New York Historical Society, April 9, 1868, and the Organization of the International Copyright Association (New York: International Copyright Association, 1868), 18.

23 Ibid.

24 Brander Matthews, American Authors and British Pirates (New York: American Copyright League, 1889), 14-15. Matthews says that these words are Lowell's, from a speech Lowell gave in England in the 1880s.

25 F. A. P. Barnard, “Open Letters,” Century, February 1886, 628.

26 Brander Matthews, "Copyright Property," New York Times, 28 August 1890.

27 Brander Matthews, "The Evolution of Copyright," in The Question of Copyright, 15.

28 Samuel L. Clemens, A Connecticut Yankee in King Arthur's Court (New York: Norton, 1982), 44. For a recent study of Twain's involvement in the copyright movement, see Siva Vaidhyanathan, Copyrights and Copywrongs: The Rise of Intellectual Property and How It Threatens Creativity (New York: New York Univ. Press, 2001), 35-80.

29 According to Tebbel, Trollope was instructed by the British Foreign Office to work on behalf of copyright (Expansion of an Industry, 2:634).

30 See James J. Barnes, Authors, Publishers, and Politicians: The Quest for an Anglo-American Copyright Agreement, 1815-1854 (Columbus: Ohio State Univ. Press, 1974), 74.

31 Matthew Arnold, “Doing As One Likes," Culture and Anarchy, ed. Samuel Lipman (New Haven: Yale Univ. Press, 1994), 56. For realist admirers of Arnold, see John Henry Raleigh, Matthew Arnold and American Culture (Berkeley and Los Angeles: Univ. of California Press, 1961), 82-83.

32 Arnold, preface to Culture and Anarchy, 5.

33 Although Arnold was an avowed copyright supporter, his vision of universal copyright granted upon publication failed to take into consideration the demands of the American book industry. He was thus interpreted as hostile to American labor. Responding to Arnold's 1880 essay "Copyright," the New York Times invoked his inattention to labor to claim that Arnold "has no sympathy with the American cry, 'free books for free men." ' In a faulty leap of logic, Arnold's indifference to labor was interpreted as evidence of both social and literary elitism (New York Times, 20 March 1880; reprinted in Publishers Weekly, 27 March 1880, 335).

34 See Raleigh, Matthew Arnold, 59. Martin T. Buinicki has recently documented Whitman's complicated position on international copyright, astutely attending to the ways in which Whitman's anti-aristocratic sentiments figured prominently in both his reception of Arnold and the literary debate that he represented ("Walt Whitman and the Question of Copyright," American Literary History 15 [summer 2003]: 248-75).

35 Arnold, "Doing As One Likes”; quoted in Raleigh, Matthew Arnold, 57.

36 Matthew Arnold, "A Word about America," in Philistinism in England and 
America, volume 10 of The Complete Prose Works of Matthew Arnold, ed. R. H. Super (Ann Arbor: Univ. of Michigan Press, 1974), 5.

37 Arnold gave this lecture many times during his 1883-84 tour of the United States; see Arnold, “Emerson,” Macmillan's Magazine, May 1884, $1-13$.

38 James B. Fry, “Mr. Matthew Arnold on America,” North American Review, May 1885, 515-19; quoted in Raleigh, Matthew Arnold, 78.

39 Ibid.; quoted in Raleigh, Matthew Arnold, 77.

40 Mark Twain, speech to the annual reunion of Connecticut's Army and Navy Club, 27 April 1887; see Matthew Arnold, General Grant, ed. John Y. Simon (Carbondale: Southern Illinois Univ. Press, 1966).

41 See H. C. Allen, The Anglo-American Relationship since 1783 (London: Adam and Charles Black, 1959), 69.

42 W. E. Simonds, "International Copyright," in The Question of Copyright, ed. Putnam, 133.

43 Lyman Abbott, “Open Letters,” Century, February 1886, 627; Henry Holt, quoted in Simonds, "International Copyright," 137.

44 Henry Holt, "Plain Talk to a Professed Pirate," Critic, 10 April 1886, 185.

45 Mark Twain, “Open Letters,” Century, February 1886, 634. This letter was reprinted in Publishers Weekly in January 1888 and was issued as a pamphlet by the American Copyright League.

46 Brander Matthews, Cheap Books and Good Books (New York: American Copyright League, 1888), 6.

47 Van Dyke, "National Sin,” 18.

48 Lowell used both these terms in correspondence with William Dean Howells at the beginning of his career in the 1860s; see Lowell to Howells, 5 July 1868 and 22 September 1869, William Dean Howells Collection, bMs Am 1784 [301], Houghton Library, Harvard University. Cited by permission of the Houghton Library.

49 Lowell to Howells, 2 November 1865, William Dean Howells Collection, Houghton Library, Harvard University. Cited by permission of the Houghton Library.

50 Proceedings of an 1888 dinner given by the British Society of Authors in honor of numerous American guests suggest the success of this mission. Lowell was roundly toasted and honored by gathered luminaries, including Walter Besant, Wilkie Collins, Edmund Gosse, and Oscar Wilde (Report of the Proceedings at the Dinner Given by the Society of Authors to American Men and Women of Letters at the Criterion Restaurant on Wednesday, July 25, 1888 [London: Society of Authors, 1888]).

51 Lowell testified before the Senate Committee on Patents on 29 January 1886. His quatrain was published in Century, May 1886, 161-62.

52 See Howells, Selected Literary Criticism, 2:96-97. These comments originally appeared in "Editor's Study,” Harper's Monthly, July 1888.

53 James Russell Lowell, “On a Certain Condescension in Foreigners,” Low- 
ell's Prose Works, vol. 3 of The Writings of James Russell Lowell (Cambridge: Printed at Riverside Press, 1890), 241-42.

54 Clarence Gohdes, American Literature in Nineteenth-Century England (Carbondale: Southern Illinois Univ. Press, 1944), 3.

55 George Haven Putnam, "International Copyright," in vol. 11 of A Library of American Literature from the Earliest Settlement to the Present Time, ed. Edmund C. Stedman and Ellen M. Hutchinson (New York: Charles Webster, 1888), 304.

56 In her study of antebellum literary piracy and reprinting, Meredith L. McGill examines the frequent use of slavery as a metaphor for piracy among pre-Civil War copyright activists (American Literature and the Culture of Reprinting, 1834-1853 [Philadelphia: Univ. of Pennsylvania Press, 2003], 4).

57 For a transcript of Lowell's address, see Critic, 3 December 1887, 282; see also William Dean Howells, “Editor's Study,” Harper's Monthly, October 1887, 804 .

58 This metaphor was also deployed by British writers incensed by American piracy, and slavery offered them a vehicle by which they pointed to the moral imperfections of American culture. For example, in 1889, British critic and writer George Moore responded to Putnam's claims of innocence with a salient analogy: "America does not yet stand within the morals of civilization; to give up slave trading and to continue to pirate English books is equivalent to saying, 'I will not break into houses, but I must stand at the street corner and pick pockets'” (Athenaeum, 12 January 1889).

59 Matthews, "American Authors," 206-7.

60 See “International Copyright," Critic 18 (1891): 213-14.

61 Ibid. 